\title{
Physics Learning Based on Practicum: Factors that Affecting Expansion
}

\author{
Eduarsyah*, Eka Murdani, Devi Astriani \\ STKIP Singkawang, Kalimantan Barat, Indonesia \\ angahcancerian@yahoo.com
}

\begin{abstract}
An object when heated will undergo expansion. Expansion of an object is affected by the expansion coefficient, temperature, and type of object substances that cause the length, area, and volume of the object and other objects differently. Based on these concepts, to investigate the comparative increase in the size of the object that is affected by factors that affect the expansion by heating the body until it reaches the equilibrium temperature. As the object under study will use a block of copper and water with each volume to be measured $10^{-5} \mathrm{~m}^{3}$ added volume ratio. With the initial temperature of each object $20^{\circ} \mathrm{C}$, both substances will be heated up to a temperature of $30^{\circ} \mathrm{C}, 35^{\circ} \mathrm{C}, 40^{\circ} \mathrm{C}, 45^{\circ} \mathrm{C}$, dan $50^{\circ} \mathrm{C}$. Both substances are then calculated and compared to the increase in volume experimentally and theoretically. After calculation, a score which indicates that the copper block and the water volume is different. Increase the volume of water is greater than the increase in the volume of copper block in each temperature increment. Both these substances are two different substances that have different volume expansion coefficient as well. So we get that expansion coefficient, temperature, and type of object substances have an affect on the expansion that occurs on an object.
\end{abstract}

Keywords: Expansion, increase in volume, temperature, type of substance

\section{Introduction}

Expansion always occurs on the objects around us are often not aware of. In addition, there are also many objects whose creation can not be separated by taking into account the concept of expansion that occurs as the installation of glass in the windows, the installation of the railroad, wiring a power pole, and so on. This was done so that they may function well as it should be. The expansion is not solely occur without any direct cause of. In general, the expansion that occurs on an object caused by a rise in temperature of the object. In addition, the expansion is also not free of the factors that influence it. Expansion that occurs in the objects around us also have many benefits that can be used for the public good. So that the expansion can be utilized for the benefit of the people, it must first know the concept and the factors that influence it.

\section{Literature Review}

Temperature is one of the fundamental quantities in physics. Temperature is a measure of the degree of heat or cold an object or measure the speed of motion of the particles in an object and can also be a measure of the average kinetic energy of the particles in an object. Objects that have a temperature high heat and cold objects have lower temperatures. The temperature of an object can undergo changes that result in changes in the properties of objects. Properties of objects that are affected by temperature changes called termometrik properties. One of the properties of objects termometrik is the expansion. Expansion is increasing the size of an object due to the influence of changes in temperature or increase in size of an object for receiving heat. In general, a substance expands when heated and contract when cooled. Large expansion and contraction of it depends on the type of substance or object. If an object is heated, the particles in it will vibrate and away from each other. Such a situation is called to expand. Meanwhile, when cooled, the particles will weaken vibration and closer together. This is called shrinking. Swelling occurs in solids, liquids, and gases (Giancoli, 2001; Halliday \& Resnick, 1991; Wulandari, 2012).

Each object is heated will not have the same gain despite heated at the same temperature. It is influenced by the length expansion coefficient owned by the particles making up the object. Length expansion coefficient $(\alpha)$ is the ratio between the length of the initial length per unit increase in body temperature. In addition, it 
can also be interpreted as the length of each 1 meter at $1^{\circ} \mathrm{C}$ temperature rise. If an object in the form of threedimensional solid is heated, there will be an expansion in the direction of the length, width, and height to the object. Therefore, the object is said to experience volume expansion. Large increase in volume is determined by the volume expansion coefficient of the respective object. Volume expansion coefficient $(\gamma)$ of an object is the ratio between the increase in the volume of material to the initial volume per unit increase in body temperature. Volume expansion coefficient of an object is equal to three times the length expansion coefficient (Giancoli, 2001; Halliday \& Resnick, 1991; Wulandari, 2012).

$\gamma=3 \alpha$

$\Delta \mathrm{V}=\mathrm{V}_{0} \Delta \mathrm{T} \gamma$
(Equation. 1)

( Equation. 2)

Specification :

$\Delta \mathrm{V}=$ Changes in volume $\left(\mathrm{m}^{3}\right)$

$\gamma=$ the volume expansion coefficient $\left(/{ }^{\circ} \mathrm{C}\right)$

$\mathrm{V}_{0}=$ initial volume of the object at $\mathrm{T}_{0}$ temperature $\left(\mathrm{m}^{3}\right)$

$\Delta \mathrm{T}=$ temperature change $\left({ }^{\circ} \mathrm{C}\right)$

Liquid water always follows the shape of the container it occupies. The container has a space or volume of liquid that just having a volume expansion. At the time the temperature of the liquid rises, the volume will increase, but its mass remains. This causes its density decreases. Equations that apply to the expansion volume of liquid equal to the volume expansion in solids, but the value is greater for the same temperature rise (Eq. 2) (Giancoli, 2001; Halliday \& Resnick, 1991; Wulandari, 2012).

\section{Methodology}

The method used in the scientific journal writing this is to make observations on the experiments carried out directly. Practicum implemented as a means of data collection. Practicum is done is to calculate the increase in the volume of two different substances, namely a block of copper and water by volume of each substance $10^{-5} \mathrm{~m}^{3}$. Both substances were then heated from the initial temperature of $20^{\circ} \mathrm{C}$ both until the temperature reaches $30^{\circ} \mathrm{C}, 35^{\circ} \mathrm{C}, 40^{\circ} \mathrm{C}, 45^{\circ} \mathrm{C}$, dan $50^{\circ} \mathrm{C}$. After that, both substances added volume calculated and the results of these calculations will be used as a reference for comparison between the increase in the volume of experimentally and theoretically.

\section{Results and Discussion}

Each object is heated will undergo expansion, whether solid, liquid, or gas. Physically, the expansion that occurs on an object can be seen in increase in length, area, and volume of the object. Expansion that occurs between two objects is affected by the length expansion coefficient, temperature, and type of substance that causes the length of objects different from one another. To prove that the expansion of objects affected by the length expansion coefficient, temperature, and type of the object substance, the research carried out by using two different substances, namely a block of copper and water with the volume of each object $10^{-5} \mathrm{~m}^{3}$ which is then heated to a second the object temperature reaches equilibrium with each other. Both of these substances will be heated to the initial temperature of $20^{\circ} \mathrm{C}$ until the object reaches a temperature of $30^{\circ} \mathrm{C}, 35^{\circ} \mathrm{C}, 40^{\circ} \mathrm{C}$, $45^{\circ} \mathrm{C}$, dan $50^{\circ} \mathrm{C}$. Block of copper will be heated by inserting a portion of the beam into the water that is heated until it reaches the predetermined temperature. To determine the temperature of the copper block, then use a digital thermometer that touched on the copper block which is outside the heated water. Each copper beam reaches predetermined temperature is $30^{\circ} \mathrm{C}, 35^{\circ} \mathrm{C}, 40^{\circ} \mathrm{C}, 45^{\circ} \mathrm{C}$, dan $50^{\circ} \mathrm{C}$, then the beam will be calculated where the value added volume obtained will be used as a comparison between the increase in the volume of experimentally and theoretically. Increase the volume of water will be calculated by means of heating water into a cylindrical glass container has a diameter of $1 \mathrm{~cm}$ and a measuring scale to determine the volume of water added when heated to a predetermined temperature is $30^{\circ} \mathrm{C}, 35^{\circ} \mathrm{C}, 40^{\circ} \mathrm{C}, 45^{\circ} \mathrm{C}$, dan $50^{\circ} \mathrm{C}$. To determine the temperature of the water will also use a digital thermometer to be put into water heated to know the temperature changes. The value obtained will be a comparison between the increase in the volume of 
experimentally and theoretically. Having conducted experiments on both the object of research, the results obtained increase the volume of the object.

\begin{tabular}{lcc}
\multicolumn{3}{l}{ Table 1: Added Volume Copper and Water Experiment Results After Heated } \\
\hline \multicolumn{1}{c}{ Temperature } & Volume of Copper $\left(\mathbf{m}^{3}\right)$ & $\boldsymbol{\Delta}$ Volume of Water $\left(\mathbf{m}^{\mathbf{3}}\right)$ \\
\hline $30^{\circ} \mathrm{C}$ & $4,9 \times 10^{-9}$ & $2,2 \times 10^{-8}$ \\
$35^{\circ} \mathrm{C}$ & $8 \times 10^{-9}$ & $2,7 \times 10^{-8}$ \\
$40^{\circ} \mathrm{C}$ & $9,3 \times 10^{-9}$ & $4,3 \times 10^{-8}$ \\
$45^{\circ} \mathrm{C}$ & $1,2 \times 10^{-8}$ & $5,1 \times 10^{-8}$ \\
$50^{\circ} \mathrm{C}$ & $1,5 \times 10^{-8}$ & $6,4 \times 10^{-8}$ \\
\hline
\end{tabular}

Having obtained the second volume of value-added objects studied experimentally, the next activity is to determine the added value of both volume of the object studied theoretically (Table. 1). Before the theoretical calculation, first known expansion coefficient of the second volume of the object.

Table 2: Volume Expansion Coefficient $(\gamma)$ (Arri, 2014; Suarsa, 2011)

\begin{tabular}{lc}
\hline Object Name & Volume Expansion Coefficient $\left({ }^{\circ} \mathrm{C}\right)$ \\
\hline Copper & $5,1 \times 10^{-5}$ \\
Water & $2,1 \times 10^{-4}$ \\
\hline
\end{tabular}

After volume expansion coefficient of the two objects is known, then performed theoretical calculations to obtain value-added volume of two objects by using the volume of an object changes the equation (Eq. 2). After calculation to obtain value-added volume of the two bodies, it has gained considerable value to compare two objects increase the volume of experimentally and theoretically that poured into the following table.

Table 3: Comparison of Volume Added Copper and Water After heated in Experiments and Theoretical

\begin{tabular}{lllll}
\hline \multirow{2}{*}{ Temperature } & \multicolumn{2}{c}{ Copper $\left(\mathbf{m}^{3}\right)$} & \multicolumn{2}{c}{ Water $\left(\mathbf{m}^{3}\right)$} \\
& Experiment & Theoretical & Experiment & Theoretical \\
\hline $30^{\circ} \mathrm{C}$ & $4,9 \times 10^{-9}$ & $5,1 \times 10^{-9}$ & $2,2 \times 10^{-8}$ & $2,1 \times 10^{-8}$ \\
$35^{\circ} \mathrm{C}$ & $8 \times 10^{-9}$ & $7,65 \times 10^{-9}$ & $2,7 \times 10^{-8}$ & $3,15 \times 10^{-8}$ \\
$40^{\circ} \mathrm{C}$ & $9,3 \times 10^{-9}$ & $1,02 \times 10^{-8}$ & $4,3 \times 10^{-8}$ & $4,2 \times 10^{-8}$ \\
$45^{\circ} \mathrm{C}$ & $1,2 \times 10^{-8}$ & $1,275 \times 10^{-8}$ & $5,1 \times 10^{-8}$ & $5,25 \times 10^{-8}$ \\
$50^{\circ} \mathrm{C}$ & $1,5 \times 10^{-8}$ & $1,53 \times 10^{-8}$ & $6,4 \times 10^{-8}$ & $6,3 \times 10^{-8}$ \\
\hline
\end{tabular}

Having obtained the value-added volume of both objects based on experimental and theoretical calculations, obtained different results between the increase in the volume of experimentally and theoretically. This can occur due to errors in measurement or an error when reading the value of the measured volume of the object (Hasanah, 2001; Tipler, 1998; Young \& Freedman, 2002). In addition, it is also known that an increase in the volume of water is greater than the increase in the volume of copper. It happened because the water has a volume expansion coefficient greater than the volume expansion coefficient of copper. If an object has a coefficient greater volume than any other object, then the object is heated if there will be a greater increase in the volume of the object that has the added volume expansion coefficient smaller volume. The greater the volume expansion coefficient of the object, the greater the increase in volume of the object when it expands (Table. 1, 2, 3).

Temperature also affects the increase in the volume of both substances. Evidently when the temperature is raised both substances, also accompanied by increasing the volume of the object either experimentally or theoretically. Added volume of the object visible when the object temperature of $50^{\circ} \mathrm{C}$, the second volume of these substances is greater than when the two substances temperature $45^{\circ} \mathrm{C}, 40^{\circ} \mathrm{C}, 35^{\circ} \mathrm{C}$, dan $30^{\circ} \mathrm{C}$ (Table. 1 , 3 ). In addition to temperature, the type of object substances also have an influence on the expansion of an object. Different types of body substances have different volumes increase. Automatically, the different types of substances objects have different volume expansion coefficient as well. As well as the research object used 
in this study is different substances that have different volume expansion coefficient and creates a different volume when heated objects (Table 1, 3) (Hasanah, 2001; Tipler, 1998; Young \& Freedman, 2002).

\section{Conclusion}

Expansion that occurs on an object is affected by several factors, namely expansion coefficient, temperature, and type of object substances. Results of research conducted experimentally and theoretically by using two different types of substances, namely copper and water which is then heated to a certain temperature, obtained data showing that the water has a greater volume increase compared with the volume of copper each increment increase the temperature where water has a volume expansion coefficient greater than the volume expansion coefficient of copper. This suggests that the expansion of an object caused by the temperature where each temperature is raised will happen the length, area, or volume of the object both experimentally and theoretically, and is caused by a type of object substances. If two objects of different substances, automatically both objects will also have a different coefficient of expansion so that the two objects have the length, area, or volume differently when heated. Value-added volume objects obtained through experiments yield different values compared with the value-added volume objects obtained through theoretical calculations. This can occur because of an error when taking measurements or error reading the measurement results.

Acknowledgement: Thanks to STKIP Singkawang who have provided assistance in the form of moral and material and to Mr. Eka Murdani, S.Si, M.PFis as both writer and Advisor to scientific journals can be resolved properly.

\section{References}

Arri, H. (2014). Pembuatan Alat Ukur dan Pengamatan Koefisien Ekspansi Thermal Dari Beberapa Material. ITB Department of Engineering Physics.

Giancoli, D. C. (2001). Fisika Jilid I (Translation). Erlangga Publishing.

Halliday, D. \& Resnick, R. (1991). Fisika Jilid I (Translation). Erlangga Publishing.

Hasanah, R. (2001). Fisika Dasar I (Thermophysics Series). Unesa University Press.

Suarsa, D. S. (2011). Pemuaian. [Online]: http://bukurobek.blogspot.in/2011/06/pemuaian.html. Accessed: (29 October 2014).

Tipler, P. A. (1998). Fisika untuk Sains dan Teknik-jilid I (Translation). Erlangga Publishing.

Wulandari, Y. (2012). 1001 Ulasan Fisika SMA. Scientific Press.

Young, H. D. \& Freedman, R. A. (2002). Fisika Universitas (Translation). Erlangga Publishing. 